\title{
CONSTRUCTION WORK TASKS DURATION: NEW METHOD OF ESTIMATION AND QUALITY CONTROL
}

\author{
Sergei Bovteev* \\ Saint Petersburg State Polytechnical University, Saint Petersburg, Russia \\ Svetlana Kanyukova \\ Saint Petersburg State Polytechnical University, Saint Petersburg, Russia \\ Vladimir Okrepilov \\ State Regional Centre for Standardization, Metrology and Testing, Saint Petersburg, Russia \\ Anna Rezvaia \\ Magadan Institute of Economics, Saint Petersburg, Russia
}

The article considers the principles of ensuring the completion of construction projects to meet the date. The authors suggest the method of assessing the progress of the project and estimating timely completion of the project based on the application of the Schedule Timeless Index (STI) and the Schedule Progress Index (SPI). The method allows to analyze dynamically the deviation of the timing of the project for prompt adoption of effective management decisions.

Key words: Planning, Project management, Performance indices, Project performance

\section{INTRODUCTION}

The modern practice of construction project execution shows that the completion date of separate projects in principle can not be delayed and ensuring timeliness of construction is an important management task. For the projects where the failure of meeting dates leads to serious, to catastrophic consequences creation of effective system of planning and control of project dates has a great meaning.

The world conventional standards of project management pays great attention to project dates planning and control, in particular, in a Guide to the Project Management Body of Knowledge (PMBOK® Guide) [01] published by the Project Management Institute (PMI), in the International Competence Baseline (ICB) [02] published by the International Project Management Association (IPMA) and others [03]. At the same time these standards cover the processes of project planning in detail, however it doesn't sufficiently state the guidelines of ensuring achievement of planned dates of separate activities and the entire project. The methodology of project management uses the term deadline as designation of date to which activity or the complex of activities or the entire project have to be completed. Failure of the deadline can be considered as project crash [04-10].

\section{MATERIALS AND METHODS}

In case of the construction project crash we need to make a rule to name the achievement of such results of the project (on duration, cost, quality, scope and other parameters) which are beyond the established limit values and lead to basic failure of the project purposes [11]. If a construction project crash happens we should necessarily state what caused such results of the project (in terms of duration, cost, quality, scope and other criteria) having gone beyond the established limit values and led to basic failure of the project purposes.

One of the main objectives of investigation of crashes and incidents is to prevent their emergence in the future. At implementation of construction projects it is necessary to provide timely data acquisition about the potential achievement of critical values of parameters which can lead the project to a catastrophic outcome and expeditious development of the effective administrative decisions, allowing to remove project parameters for a framework of critical conditions.

For ensuring construction project to complete on time it is necessary to create the effective system of tracking and control of project dates [12, 13], one of such methods is presented below.

The revisions of the construction project can be performed with the frequency equal to one week. 
The actual project progress should be checked to the data which is called as the status date. Schedule tracking by criterion of time has to be carried out according to functionality project management software, in particular Oracle Primavera P6 [14] and Microsoft Project Professional [15]. The actual activities start and finish dates are checked daily.

The parameter of the remaining duration for all performed project activities is weekly evaluated. We suppose to take a forecast of an expected date of activity finish date as an input of this parameter.

Remaining Duration (RD) - the amount of time which needs to be spent of the status date for the activity completion. If the activity is performed according to the schedule, the Remaining Duration will be determined by a formula:

$\mathrm{RD}=$ Total Duration - Actual Duration

Otherwise it is necessary to specify the forecast finish date (FFD) of activity:

FFD = Status Date + Remaining Duration

Here, the Remaining Duration will be determined by an expert way or on the basis of calculation depending on the type of work and it's implementation method.

Before the start of the project it is important to accept a certain forecasting period, it is necessary in order to control not only those activities which are planned to be performed within the status date, and not only behind the schedule, but also the activities scheduled to start within the forecasting period (usually from 4 to 8 weeks). Thus, for activities planned within this period it is nec- essary to specify an expected date of their start and their expected duration.

The important problem of control consists of evaluation on the basis of collected and processed actual data about activities' performance and an assessment of the entire project condition [16, 17]. As a result of such periodical assessment it is necessary to produce a short, laconic Project Status Report which reflect a situation for the following reporting to project stakeholders $[18,19]$.

The project manager and project team usually are expecting to get answers to the following key questions:

- If the project completion date is going to meet the deadline?

- If the earned project value is equal to the planned project value?

The essence of an assessment of possibility of the project completion date as to the project target date is shown on curve (Figure 1). Here: $T_{\text {st }}$ - start project date; $T_{\text {tar }}$ - target completion project date; $T_{\text {for }}$ - forecast completion project date, depends on the achieved progress of the project, at the project start date is equal to $T_{\text {tar, }}$ at the project completion date is equal to $T_{\text {act }} ; T_{\text {act }}$ - actual completion project date, when the project will be finished; $\Delta T(t)=T_{\text {tar }}-T_{\text {for }}$ - function of project dates deviation.

The curve (Figure 1) shows that, despite existence of the negative forecast of project completion date deviations, these deviations don't leave out of the set limits (see the admissible value of deviation) and the project to be finished on time.

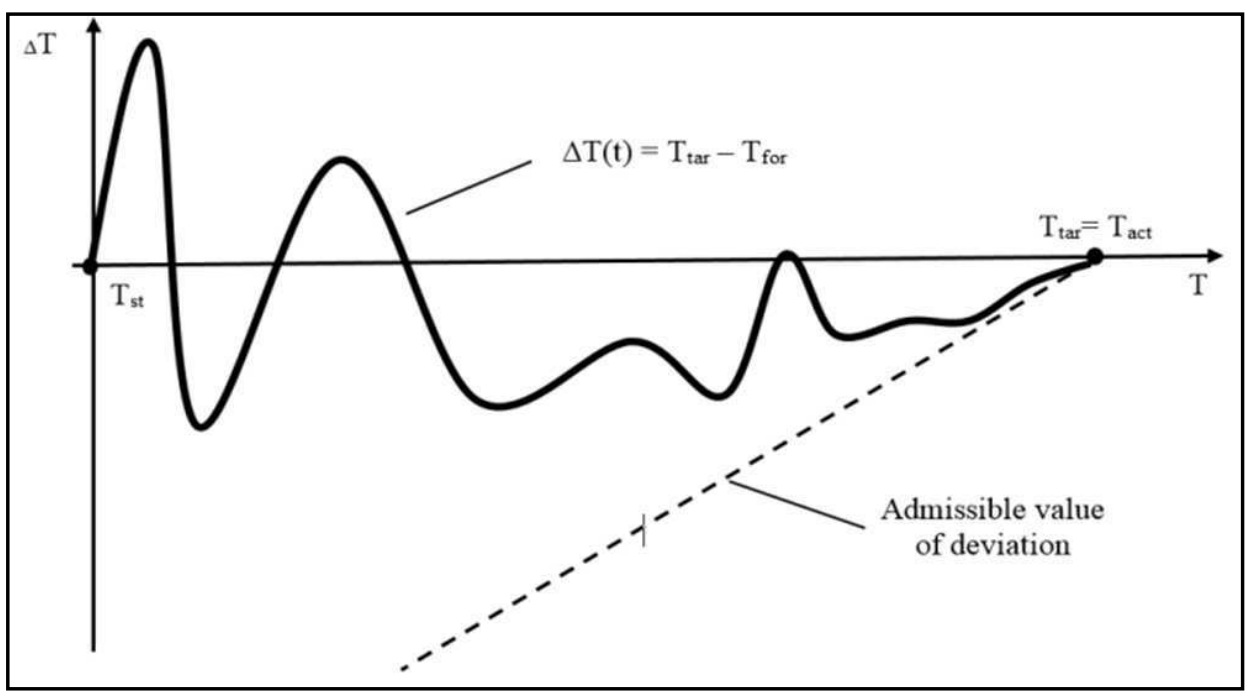

Figure 1: The curve of deviation of the forecast project completion date according to the status project date in case of completion project date is on time 
The curve (Figure 2) shows that, the forecast of deviations from a target date of the project left out the set limits that led finally to failure of project deadline. The time point where the function of a deviation of the forecast project completion date according to the status date exceeded the limit of admissible value, is "a point of no return", i.e. it is possible to consider that further beyond this point it is impossible to bring the project back on track.

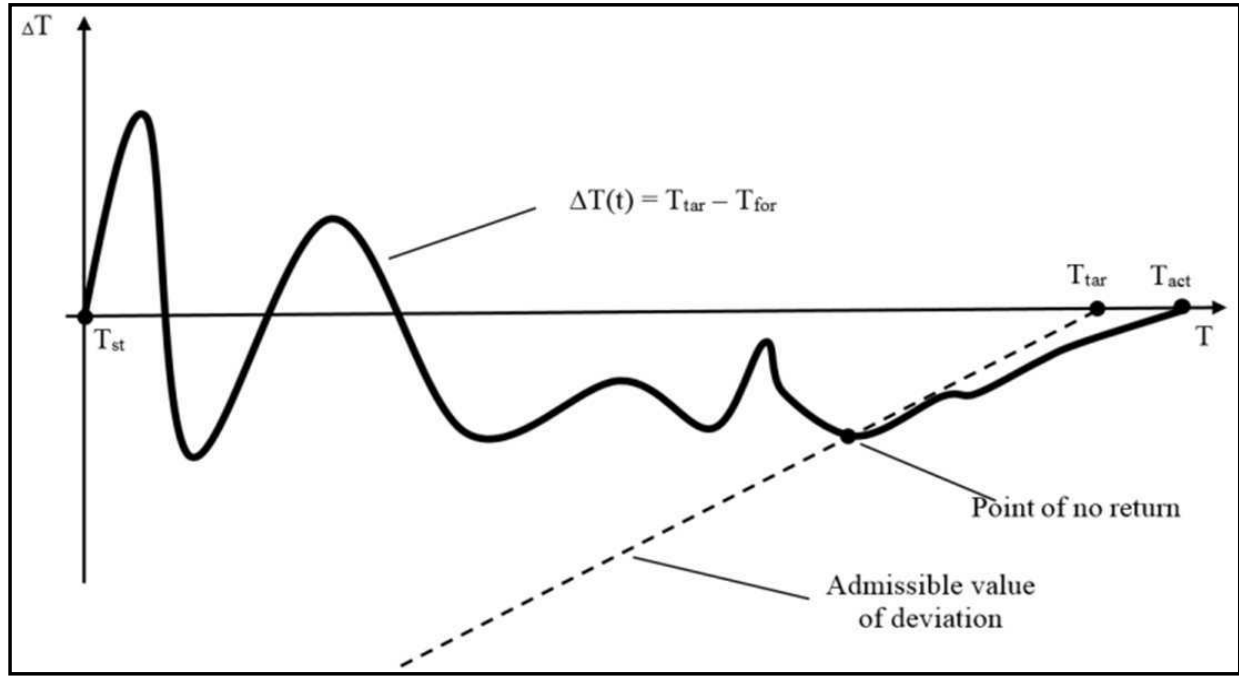

Figure 2: The curve of deviation of the forecast project completion date according the status date in case of failure of deadline of the project

\section{RESULTS AND DISCUSSION}

It is necessary to consider two main tracked features to estimate the status of the entire project: timeliness of the project completion date and extent of progress of activities performing in comparison with the schedule [11].

The Schedule Timeless Index (STI) can be calculated by the following formula:

$$
\mathrm{STI}=\frac{\mathrm{T}_{\mathrm{tag}}-\mathrm{T}_{\text {for }}}{\mathrm{T}_{\mathrm{tag}}-\mathrm{SD}}
$$

where $T_{\text {tag }}$ - target completion date of the project is defined during the approval of the baseline; $\mathrm{T}_{\text {for }}$ - expected completion date of the project, i.e. date of approach of a finishing milestone of the project, determined by the current schedule for status date; SD - status date.

The value of the STI depends on amount of time which remains before finish of the project, i.e. to be able to make management decisions.

The actual project progress can be measured as the ratio of activities which are actually completed as per the status date to amount of activities which has to be completed according to the baseline schedule. In this case the completion of activities is considered both the numerator, and the denominator i.e. if an activity is being performed now it is considered incomplete that creates a certain reserve. If project activities are equal in terms of importance, it is possible to reduce calculation of this index to a quantitative assessment: Ncompl / Nplanned, where $\mathrm{N}_{\text {compl }}$ the amount of activities, which are actually completed as of the status date; $\mathrm{N}_{\text {planned }}$ - the amount of activities which have to be completed as of status date according to the baseline. This index will correspond to the Schedule Performance Index (SPI) from the Earned Value Management [20- 22].

However it is necessary to consider the time which remains before the completion of the project, and also to carry out an assessment of value of a deviation of the actual parameters from planned, instead simply define a ratio of the performed and planned activities. Taking into account these factors, a relative indicator - the Schedule Progress Index (SPI) - will be calculated by a formula:

SPI $=\left(\frac{\frac{\mathrm{N}_{\text {compl }}}{\mathrm{N}_{\text {planned }}}-1}{\mathrm{~T}_{\text {tar }}-\mathrm{SD}}\right)$

The STI can be considered as the basic, and the SPI - as an additional. Values of these indexes aren't interconnected therefore change of one index will directly not influence the value of other. It is necessary to estimate the limit of these indexes to define in what "zones" the projects are in terms of time [11]. 
Table 1: The example of successful implementation of the project

\begin{tabular}{|c|c|c|c|c|c|c|c|c|}
\hline $\begin{array}{l}\text { Status } \\
\text { Date }\end{array}$ & $\begin{array}{c}\text { Time to } \\
\text { Completion }\end{array}$ & $\begin{array}{l}\text { Plan Amount } \\
\text { of activities }\end{array}$ & $\begin{array}{c}\text { Actual Amount } \\
\text { of activities }\end{array}$ & $\begin{array}{l}\text { Project } \\
\text { Duration } \\
\text { Variance }\end{array}$ & STI & STI Zone & SPI & SPI Zone \\
\hline 0 & 210 & 0 & 0 & 0 & & & & \\
\hline 7 & 203 & 25 & 35 & 4 & 0,020 & Dark green & 0,414 & Dark green \\
\hline 14 & 196 & 75 & 90 & 7 & 0,036 & Dark green & 0,214 & Dark green \\
\hline 21 & 189 & 125 & 150 & 10 & 0,053 & Dark green & 0,222 & Dark green \\
\hline 28 & 182 & 165 & 210 & 6 & 0,033 & Dark green & 0,315 & Dark green \\
\hline 35 & 175 & 210 & 280 & 2 & 0,011 & Dark green & 0,400 & Dark green \\
\hline 42 & 168 & 260 & 350 & 0 & 0,000 & Dark green & 0,433 & Dark green \\
\hline 49 & 161 & 330 & 400 & -3 & $-0,019$ & Light green & 0,277 & Dark green \\
\hline 56 & 154 & 400 & 460 & -5 & $-0,032$ & Light green & 0,205 & Dark green \\
\hline 63 & 147 & 470 & 530 & -4 & $-0,027$ & Light green & 0,182 & Dark green \\
\hline 70 & 140 & 540 & 600 & -2 & $-0,167$ & Light green & 0,167 & Dark green \\
\hline 77 & 133 & 610 & 650 & -8 & $-0,104$ & Light green & 0,104 & Dark green \\
\hline 84 & 126 & 720 & 700 & -10 & $-0,069$ & Light green & 0,069 & Dark green \\
\hline 91 & 119 & 830 & 820 & -7 & $-0,059$ & Light green & $-0,021$ & Dark green \\
\hline 98 & 112 & 930 & 950 & -8 & $-0,071$ & Light green & 0,040 & Dark green \\
\hline 105 & 105 & 1020 & 1040 & -10 & $-0,095$ & Light green & 0,039 & Dark green \\
\hline 112 & 98 & 1090 & 1110 & -12 & $-0,052$ & Light green & 0,040 & Dark green \\
\hline 119 & 91 & 1160 & 1180 & -6 & $-0,066$ & Light green & 0,61 & Light green \\
\hline 126 & 84 & 1230 & 1260 & -8 & $-0,095$ & Light green & 0,021 & Light green \\
\hline 133 & 77 & 1300 & 1310 & -4 & $-0,052$ & Light green & $-0,086$ & Light green \\
\hline 140 & 70 & 1390 & 1350 & -9 & $-0,129$ & Light green & $-0,086$ & Light green \\
\hline 147 & 63 & 1500 & 1450 & -11 & $-0,175$ & Yellow & $-0,111$ & Yellow \\
\hline 154 & 56 & 1620 & 1500 & -8 & $-0,143$ & Light green & $-0,278$ & Yellow \\
\hline 161 & 49 & 1690 & 1590 & -6 & $-0,122$ & Light green & $-0,254$ & Yellow \\
\hline 168 & 42 & 1760 & 1670 & -6 & $-0,143$ & Light green & $-0,256$ & Light green \\
\hline 175 & 35 & 1820 & 1790 & -4 & $-0,114$ & Light green & $-0,099$ & Light green \\
\hline 182 & 28 & 1880 & 1870 & -3 & $-0,107$ & Light green & $-0,040$ & Light green \\
\hline 189 & 21 & 1930 & 1915 & -2 & $-0,095$ & Light green & $-0,078$ & Light green \\
\hline 196 & 14 & 1960 & 1955 & -2 & $-0,143$ & Light green & $-0,038$ & Light green \\
\hline 203 & 7 & 1980 & 1975 & -1 & $-0,143$ & Light green & $-0,076$ & Light green \\
\hline 210 & 0 & 2000 & 2000 & 0 & \multicolumn{4}{|c|}{ Success } \\
\hline
\end{tabular}

If the STI $>0$ or the SPI $>0$ - project implementation is in a dark green zone.

If the $-0,15<\mathrm{STI}<0$ or the $-0,5<\mathrm{SPI}<0$ - project implementation is in a light green zone.

If the $-0,3<\mathrm{STI}<-0,15$ or the $-0,3<\mathrm{SPI}<-0,15$ - project implementation is in a yellow zone.

If the $\mathrm{STI}<-0,3$ or the SPI $<-0,3-$ project implementation is in a red zone.

When the value of two indicators is in a dark green zone - the project implementation goes better than planned.
When the value of at least one of two indicators exceeds the dark green zone into the light green, it indicates that it is close to it's negative deviations from the schedule, but these deviations are insignificant and they can be neglected.

When the value of at least one of two indicators exceeds the light green zone into the yellow one - the schedule of the project demands recalculation. In this case it is necessary to find opportunities for acceleration of the remained activities or if it is impossible or it is inefficient, to negotiate 
agreement of moved project deadline [23-25].

In case when the value of at least one of two indexes exceeds the yellow zone into the red one - the project can be considered as failed on dates in spite of the fact that there is still time before project completion. It should be noted that the extreme value of these indexes directly depend on amount of the reserve put at the schedule evalu- ation. If the project is carried out according to rather intense schedule which isn't providing considerable internal reserves, extreme values of indexes have to be minimum, and vice versa. Anyway, it is necessary to approach determination of the extreme values of indexes responsibly. The example of successful implementation of the project is presented in Table 1.

Table 2: The example of failure implementation of the project

\begin{tabular}{|c|c|c|c|c|c|c|c|c|}
\hline $\begin{array}{l}\text { Status } \\
\text { Date }\end{array}$ & $\begin{array}{c}\text { Time to } \\
\text { Completion }\end{array}$ & $\begin{array}{l}\text { Plan Amount } \\
\text { of activities }\end{array}$ & $\begin{array}{l}\text { Actual Amount } \\
\text { of activities }\end{array}$ & $\begin{array}{c}\text { Project } \\
\text { Duration } \\
\text { Variance }\end{array}$ & STI & STI Zone & SPI & SPI Zone \\
\hline 0 & 210 & 0 & 0 & 0 & & & & \\
\hline 7 & 203 & 25 & 35 & 4 & 0,020 & Dark green & 0,414 & Dark green \\
\hline 14 & 196 & 75 & 90 & 7 & 0,036 & Dark green & 0,214 & Dark green \\
\hline 21 & 189 & 125 & 150 & 10 & 0,053 & Dark green & 0,222 & Dark green \\
\hline 28 & 182 & 165 & 210 & 6 & 0,033 & Dark green & 0,315 & Dark green \\
\hline 35 & 175 & 210 & 280 & 2 & 0,011 & Dark green & 0,400 & Dark green \\
\hline 42 & 168 & 260 & 350 & 0 & 0,000 & Dark green & 0,433 & Dark green \\
\hline 49 & 161 & 330 & 400 & -3 & $-0,019$ & Light green & 0,277 & Dark green \\
\hline 56 & 154 & 400 & 460 & -5 & $-0,032$ & Light green & 0,205 & Dark green \\
\hline 63 & 147 & 470 & 530 & -4 & $-0,027$ & Light green & 0,182 & Dark green \\
\hline 70 & 140 & 540 & 600 & -2 & $-0,014$ & Light green & 0,167 & Dark green \\
\hline 77 & 133 & 610 & 650 & -8 & $-0,060$ & Light green & 0,104 & Dark green \\
\hline 84 & 126 & 720 & 750 & -10 & $-0,079$ & Light green & 0,069 & Dark green \\
\hline 91 & 119 & 830 & 820 & -7 & $-0,059$ & Light green & $-0,021$ & Dark green \\
\hline 98 & 112 & 930 & 950 & -8 & $-0,071$ & Light green & 0,040 & Dark green \\
\hline 105 & 105 & 1020 & 1040 & -10 & $-0,095$ & Light green & 0,039 & Light green \\
\hline 112 & 98 & 1090 & 1110 & -12 & $-0,122$ & Light green & 0,039 & Light green \\
\hline 119 & 91 & 1160 & 1180 & -6 & $-0,066$ & Light green & 0,040 & Yellow \\
\hline 126 & 84 & 1230 & 1260 & -8 & $-0,095$ & Light green & 0,061 & Red \\
\hline 133 & 77 & 1300 & 1310 & -4 & $-0,052$ & Light green & 0,021 & Red \\
\hline 140 & 70 & 1390 & 1350 & -9 & $-0,129$ & Light green & $-0,086$ & Red \\
\hline 147 & 63 & 1500 & 1450 & -11 & $-0,175$ & Yellow & $-0,111$ & Red \\
\hline 154 & 56 & 1620 & 1500 & -15 & $-0,268$ & Yellow & $-0,278$ & Red \\
\hline 161 & 49 & 1690 & 1560 & -20 & $-0,408$ & Red & $-0,330$ & Red \\
\hline 168 & 42 & 1760 & 1630 & -20 & $-0,476$ & Red & $-0,369$ & Red \\
\hline 175 & 35 & 1820 & 1680 & -20 & $-0,571$ & Red & $-0,462$ & Red \\
\hline 182 & 28 & 1880 & 1730 & -18 & $-0,643$ & Red & $-0,598$ & Red \\
\hline 189 & 21 & 1930 & 1770 & -15 & $-0,714$ & Red & $-0,829$ & Red \\
\hline 196 & 14 & 1960 & 1800 & -13 & $-0,929$ & Red & $-1,224$ & Red \\
\hline 203 & 7 & 1980 & 1840 & -12 & $-1,714$ & Red & $-2,121$ & Red \\
\hline 210 & 0 & 2000 & 1880 & -10 & & & ure & \\
\hline
\end{tabular}




\section{CONCLUSION}

Herein we state a system of project parameters indication that allows to track effectively the condition of activities (a complex of activities) in particular and the entire project, as well as to provide timely information on approach of critical parameters which can lead to substantial, catastrophic effects. This method allows to make an assessment of the project progress in order to make the effective management decisions, allowing to remove project parameters from the framework of critical conditions. The proposed method can be used in the construction project management. This method can be used to ensure completion of the project or the key milestones on time.

\section{REFERENCES}

1) Archibald, R.D. (2003): Managing High-Technology Programs and Projects, 3rd Edition $p$. 396.

2) Bovteev, S., Terentieva, E. (2014): Construction project schedule control, Projectand Program Management, No.2, pp. 158-173.

3) Ćetković J., Rutešić S., Zarković M., Knežević M., Vatin N. (2015): Primary directions and advancements in competitiveness of montenegrin construction sector, Procedia Engineering, 117 (1), pp. 780-790.

4) Ćetković, J., Knežević, M., Žarković, M., Murgul, V., Vatin, N. Development and competitiveness improvement of the construction sector in Montenegro (2014) Applied Mechanics and Materials, Vols. 638-640, pp. 2465-2470.

5) Chatfield, C., Johnson, T. (2013): Microsoft Project 2013. Step by step, Redmond, Washington.

6) Chegotova, E.V. (2012): The Role of technical customer in the organization of investment activities in construction, Magazine of Civil Engineering, 29(3), pp. 5-11.

7) Heldman, K. (2009): PMP: Project Management Professional Exam study Guide, 5th Edition, p. 677.

8) Homutinnikova, K. C. (2009): Evaluation Criteria methods of verification used in managing construction projects, Management projects and programs, No.4, pp. 312-323.

9) ICB - IPMA Competence Baseline (2006): Version 3.0. Nijkerk, The Netherlands.
10) L.Lynch. (2010): On Time and under budget: a project management method critical chain (2010) pp. 354.

11) Project Management Body of Knowledge (2012): 5th ed. Project Management Institute. Newtown Square, Pennsylvania.

12) Project Management in Construction. Fourth Edition. pp. 285.

13) Ptukhina, I.S. (2011): Methodology of the distribution of economic justice the perpetrators for the delay of completion, Kuban state agrarian University, 04(68), pp. 383-394.

14) Pukhkal, V., Murgul, V., Garifullin, M. (2015): Reconstruction of Buildings with a Superstructure Mansard: Options to Reduce Energy Intensity of Buildings, Procedia Engineering, Vol. 117, pp. 624-627.

15) Rutešić S., Ćetković J., Knežević M., Žarcković M., Vatin N. (2015): Institutional framework, current investments and future strategic direction for development of construction sector in Montenegro, Procedia Engineering, 117 (1), pp. 642-650.

16) Rutešić S., Ćetković J., Žarcković M., Knežević M., Vatin N. (2015): Analysis of the situation in montenegrin civil engineering sector from the point of application of national regulations and the EU technical standards in construction, Procedia Engineering, 117 (1), pp. 905-915.

17) Schlagbauer, D., Heck, D. (2013): Change in output performance due to prolonged work, ISEC 2013 - 7th International Structural Engineering and Construction Conference: New Developments in Structural Engineering and Construction, pp. 1375-1380.

18) Suetin, S.N., Titov, S.A. (2014): Project portfolio management: strategic level of project management, Economy and Entrepreneurship, 5-2 (46-2), pp. 509-515.

19) Vatin, N.I., Kolosova, N.B., Berdyugin, I.A. (2013): Efficiency of application of automatic control systems, accugrade in construction, Construction of Unique Buildings and Structures, 4 (9), pp. 29-35.

20) W. Lipke. (2012): Earned schedule contribution to project management, PM World Journal, Vol. 1, Issue 2.

21) Werkl, M, Heck, D. (2011): Coping with incompleteness: An approach using time and production related compensation, ISEC 
22) - 6th International Structural Engineering and Construction Conference: Modern Methods and Advances in Structural Engineering and Construction, pp. 279-284.

23) Williams, D.L. Krazer, E.B. (2012): Oracle Primavera P6 Version 8: Project and Portfolio Management: A comprehensive Guide to managing projects, resources, and portfolios using Primavera P6, through version 8.2. Birmingham \& Mumbai: PACKT Publishing.

24) Yakovlev, Y.V. (2010): Mechanisms of management of complex investment and con- struction project, Moscow: Creative house.

25) Yu. N. (2008): Lapygin Project management: from planning to evaluation, Moscow: Omega-L, p. 252.

26) Zakieva, N.M., Sirazetdinov, R.M. (2011): Corporate project management system as management mechanism of innovative projects in investment-construction complex, News of the Kazan, No.3, pp. 211-218.

Paper sent to revision: 07.02.2016.

Paper ready for publication: 10.03.2016. 
doi:10.5937/jaes14-10443

Broj rada: 14(2016)1, 362

\section{METOD OCENJIVANJA SPOSOBNOSTI ZAVRŠAVANJA GRAĐEVINSKOG PROJEKTA DO UTVRĐENOG DATUMA I KONTROLA KVALITETA}

Sergei Bovteev, Državni Politehnički Univezitet, St. Petersburg, Rusija

Svetlana Kanyukova, Državni Politehnički Univezitet, St. Petersburg, Rusija

Vladimir Okrepilov, Državni Politehnički Univezitet, St. Petersburg, Rusija

Anna Rezvaia, Državni Politehnički Univezitet, St. Petersburg, Rusija

U radu se rasmatraju principi obezbeđivanja završavanja građevinskih projekata do utvrđenog datuma. Predložena metodika ocenjivanja progresa projekta i ocenjivanja mogućnosti svojevremenog završetka projekta, osnovana je na primeni pokazatelja ScheduleTimelessIndex (STI) i ScheduleProgressIndex (SPI). Metodika dozvoljava dinamično analiziranje otstupanje rokova projekta za operativno donošenje efektivnih upravljačkih rešenja.

Ključne reči: Planiranje, Upravljanje projektima, Indeksi performanse, Performanse projekta 